\title{
Lithostratigraphic classification of the Tsodilo Hills Group: a Palaeo- to Mesoproterozoic metasedimentary succession in NW Botswana
}

\author{
Marek Wendorff', Andrzej Świąder ${ }^{2}$ \\ ${ }^{1}$ AGH University of Science and Technology, Faculty of Geology, Geophysics and Environmental Protection, Department of \\ Environmental Analysis, Geological Mapping and Economic Geology; al. A. Mickiewicza 30, 30-059 Krakow, Poland; \\ e-mail:wendorff@agh.edu.pl; ORCIDID:0000-0003-4607-8906 \\ ${ }^{2}$ AGH University of Science and Technology, Faculty of Geology, Geophysics and Environmental Protection, Department of \\ Environmental Analysis, Geological Mapping and Economic Geology; al. A. Mickiewicza 30, 30-059 Krakow, Poland; \\ e-mail: andrzej.swiader@agh.edu.pl; ORCID ID: 0000-0003-1641-7962
}

(C) 2019 Authors. This is an open access publication, which can be used, distributed and reproduced in any medium according to the Creative Commons CC-BY 4.0 License requiring that the original work has been properly cited.

Received: 22 October 2019; accepted: 20 December 2019; first published online: 30 December 2019

\begin{abstract}
The Tsodilo Hills Group strata exposed in the Tsodilo Hills are an association of meta-arenites, metaconglomerates, quartz-mica schists, sandstone, red siltstone and sedimentary breccia deposited on an open siliciclastic marine shelf between the Late Palaeoproterozic and Late Mesoproterozoic, and outcropping in NW Botswana. The succession is dominated by three micaceous quartzite units interlayered with subordinate lenses and wedges of other rock types. Facies gradients from $\mathrm{S}$ to $\mathrm{N}$ are expressed by: decreasing content of muscovite at all levels of metasediment organisation from thin wedge-shaped units to thick quartzite complexes, as well as a decrease in pebble content and increase in arenaceous matrix in some metaconglomerate beds, matching regional palaeotransport direction. Well-rounded pebbles of extrabasinal rocks are flat, suggesting redeposition from a beach environment. Lenticular conglomeratic bodies with erosional lower boundaries represent infills of local incisions in the sandy bottom sediments. The abundance of laterally discontinuous lithological units reflects shelf palaeotopography controlled and modified by deposition and migration of large bed forms, ranging from megaripple marks (or submarine dunes) to sand waves. Deposition was influenced by tides and two regressive events. The older regression resulted in a marker unit of tidal mudflat-related red-bed facies: mudstone, siltstone, channel-fill sandstone and sedimentary breccia. The second regression is indicated by a tabular conglomerate marker reflecting increased input of coarse terrigenous material.
\end{abstract}

Keywords: lithostratigraphy, siliciclastic shelf, Proterozoic, Botswana

\section{INTRODUCTION}

The Tsodilo Hills rise over $420 \mathrm{~m}$ above the surrounding Kalahari Desert in NW Botswana in the region where the Neoproterozoic Damara belt crosses the country (Fig. 1). This Pan African orogen extends from Zambia and Congo in the NE, where it is known as the Katangan belt, or the Lufilian Arc, to Namibia in the SW. The Tsodilo
Hills, located ca. $40 \mathrm{~km}$ to the west of the Okavango River (Fig. 2), form three hills traditionally called Nxum Ngxo (Male), Nxum Di (Female) and Picannin (Child), the cliffs and steep slopes of which expose the Tsodilo Hills Group strata (Key \& Ayers 2000, Wendorff 2005). A broad expanse of the surrounding terrain is covered by the Cretaceous to Recent Kalahari beds, composed of lacustrine, fluvial and aeolian sediments that 
unconformably cover older strata (Carney et al. 1994). Exposures of rocks older than the Kalahari beds are extremely rare in the region, which is why boundaries of the regional units shown on the schematic map (Fig. 1) are imprecise, chiefly reflecting interpretations of the geophysical data (Meixner \& Peart 1984, Carney et al. 1994, Key \& Ayers 2000).

Based upon an ${ }^{40} \mathrm{Ar} /{ }^{39} \mathrm{Ar}$ age of $490.0 \pm 2.3 \mathrm{Ma}$ on muscovite grains from quartz-muscovite schist (Singletary et al. 2003), interpreted as the age of cooling after regional metamorphism, the regional position and lithological similarities with some units of the Damara Belt in Namibia, a Neoproterozoic age of the Tsodilo Hills Group was initially suggested (Wendorff 2005). However, the most recent geochronological work based on detrital zircon dating verified the depositional age of the Tsodilo rock succession by assigning its origin to the period spanning the Late Palaeoproterozic to Late Mesoproterozoic (Mapeo et al. 2019). Therefore, the Tsodilo Hills metasedimentary rocks are much older than thought previously and appear to be age-equivalent to several sedimentary rock units known in Africa as parts of the Kalahari Craton, Congo and Congo-Tanzania Craton as well as in South America within the São Francisco Craton (Mapeo et al. 2019).

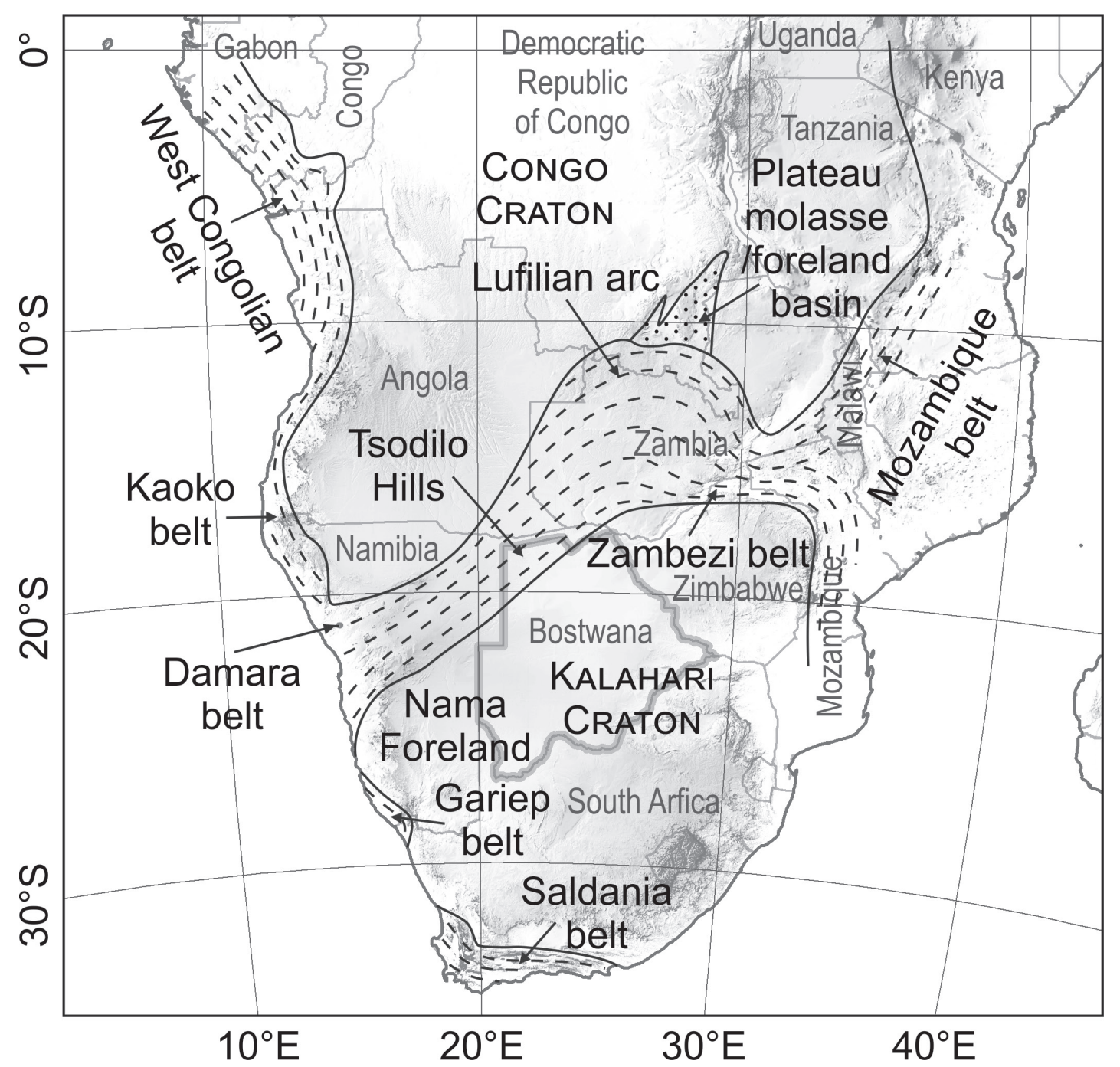

Fig. 1. Position of the Tsodilo Hills Group outcrop in the framework of the Neoproterozoic-Lower Palaeozoic Pan-African belts of central and southern Africa and the adjacent Cratons (modified from Wendorff 2005) 


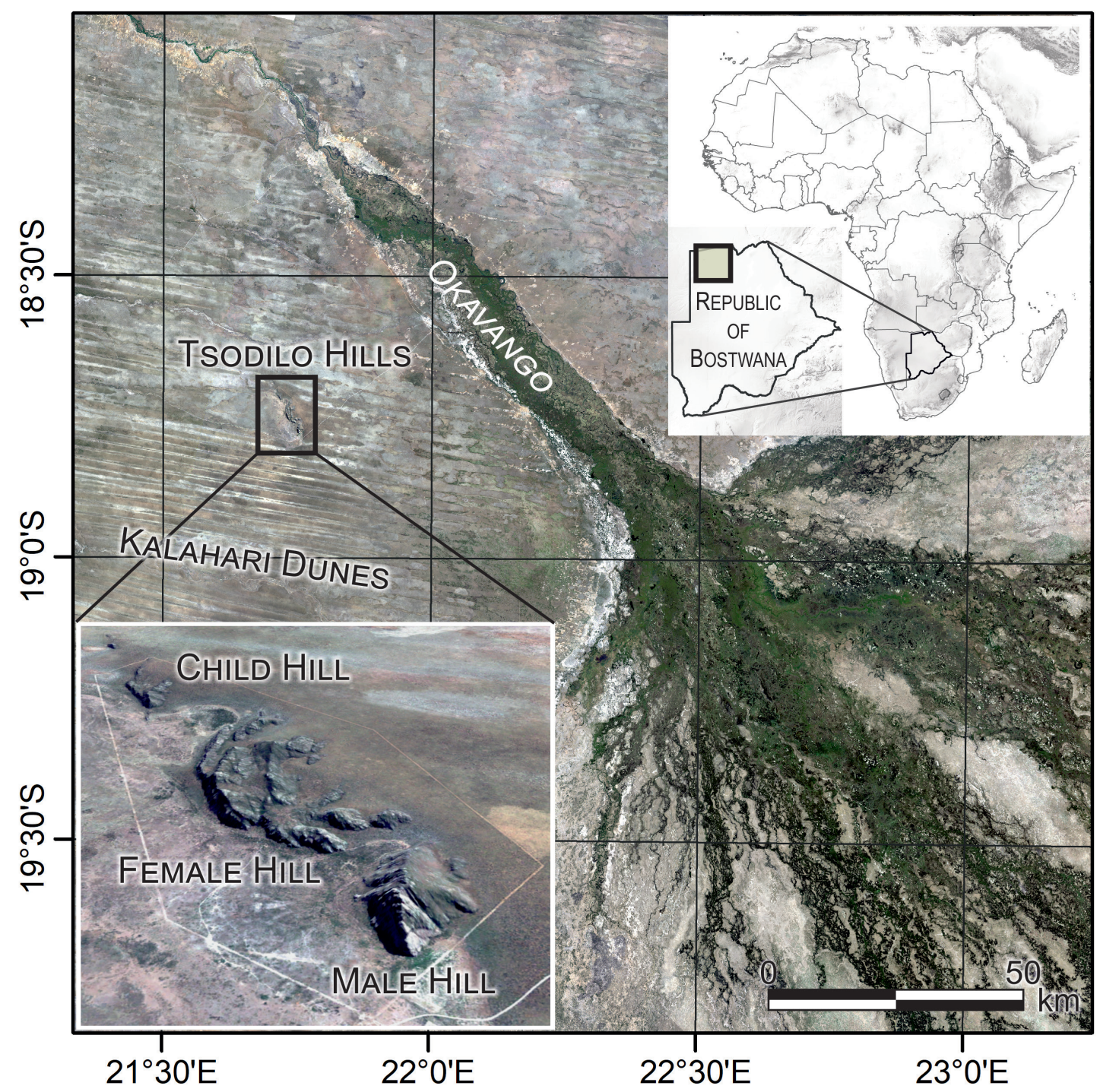

Fig. 2. Location of the Tsodilo Hills relative to the Okavango River in NW Botswana (Landsat 8 natural colours composition). Inset shows oblique view of the three Hills seen from the SW (Sentinel 2 natural colours composition). In this region, relict seif dunes of the Kalahari beds are clearly visible on the satellite image

This age dating sheds new light on a special role of the Tsodilo Hills Group succession as a stratigraphic unit that may become one of the important elements contributing to inter-regional palaeogeographical reconstructions of the Proterozoic palaeocontinental masses, which are now scattered and belong to various crustal elements of Africa and South America. Marine siliciclastic deposits are excellent repositories of information important for large-scale tectonostratigraphic reconstructions because siliciclastic sedimentary successions reflect evolutionary stages of depositional basins and the adjacent land masses.
Therefore, a detailed stratigraphic record of the Tsodilo Hills Group may in the future serve as a guide for mapping of age-equivalent, genetically similar regions and for inter-regional correlation. Considering that, the aim of this paper is to present the lithostratigraphic classification of the Tsodilo Hills Group based on as yet unpublished fieldwork results, integrating lithological features with fundamental sedimentological characteristics. These observations are synthesised and shown in a new map documenting the distribution, geometries and relations between the identified lithostratigraphic units. 


\section{METHODS}

Geological mapping was conducted at the scale of 1:10 000 on a topographic map and with the aid of aerial photographs produced by the Botswana Department of Surveys and Mapping. Subsequently, the interpreted field map was reduced to the one published here. In most cases, the moderately metamorphosed rocks exposed in the slopes and cliffs of the Tsodilo Hills reveal their primary sedimentary structures, and often also textures. The grain-size scale published by Wentworth (1922) was applied in the classification of the arenaceous strata and bed thickness classification follows the Ingram (1954) scale. Furthermore, mineral composition reported in the lithological descriptions takes into account field observations only.

The lithostratigraphic logs were constructed on the basis of geological cross-sections and apparent thicknesses recalculated to true values. The size of pebbles is characterised by the length of their long axis, i.e. the maximum clast size, which reflects maximum competence of the transporting current. Occurrences of bipolar palaeocurrent directions are mentioned only to emphasize here that the depositional processes that formed the Tsodilo succession were influenced by marine tidal action, as discussed by Wendorff (2005). It must be noted that a part of the area is exposed in steep, in places precipitous, cliffs, therefore the amount of detail that can be observed varies both vertically and laterally.

\section{GEOLOGICAL BACKGROUND}

The rocks of the Tsodilo Hills were initially described in two unpublished accounts. Wright (1956) characterised them as an association of "micaceous schist, quartz-rich layers, grits and pebbly beds". Vermaak (1962) subdivided the succession into four units, which he called "stages", and observed that some of them are laterally discontinuous. Both authors also noted the occurrences of an accessory mineral assemblage: muscovite-kyanite-haematite-tourmaline-dumortierite. Subsequently, Wendorff (2005) revised the existing stratigraphic scheme and presented preliminary observations on sedimentary features of this metasedimentary succession, mineral composition, facies trends and palaeocurrent patterns. On this basis he suggested that the deposition of the Tsodilo Hills Group strata took place on a tidally-influenced open continental shelf influenced by two regression-transgression cycles and one sea-level lowstand marked by a rapid increase of supply in pebbly deposits. The shelf was supplied with mature siliciclastic material and influenced by a combination of tidal currents generally oriented NNW-SSE and eastwards-oriented littoral longshore currents. It was further suggested that the Tsodilo Hills Group arenites were deposited as supermature siliciclastic sediments (Wendorff 2005, Mapeo et al. 2019), which would imply either very low sedimentation rates and prolonged reworking within the shelf environment, or polycyclic genesis of the detritus supplied to the basin, or both.

The succession is deformed by several fault zones varying in scale from locally present small thrust zones of limited lateral extent passing laterally into shear zones, a few small-scale reverse faults to one major thrust. The latter displaces the affected strata towards the south-west in the Male Hill slopes. However, the extent of this deformation decreases laterally across the western slope of the Male Hill, and continues in the south-eastern part of the Female Hill as a thin shear zone. The direction of dislocation towards the SE is common to the thrusts and shear zones at all scales.

\section{LITHOSTRATIGRAPHIC UNITS OF THE TSODILO HILLS GROUP}

Lateral variations in lithological association, thickness and geometry of the mappable lithostratigraphic divisions exposed in the slopes of the Male and Female Hills (Fig. 3) demonstrate differences that require them to be discussed separately as two depositional suites. However, there are instances where lithological continuity across the depression separating the two hills, which is filled with the Kalahari beds sand, can be suggested with confidence. Such correlations are reflected in the descriptions below and discussed in the final section. The descriptions follow the ascending order summarised in the lithostratigraphic columns (Fig. 4) which document the successions, and include true thicknesses of the units, as intersected along two reference lines A-B and C-D. 


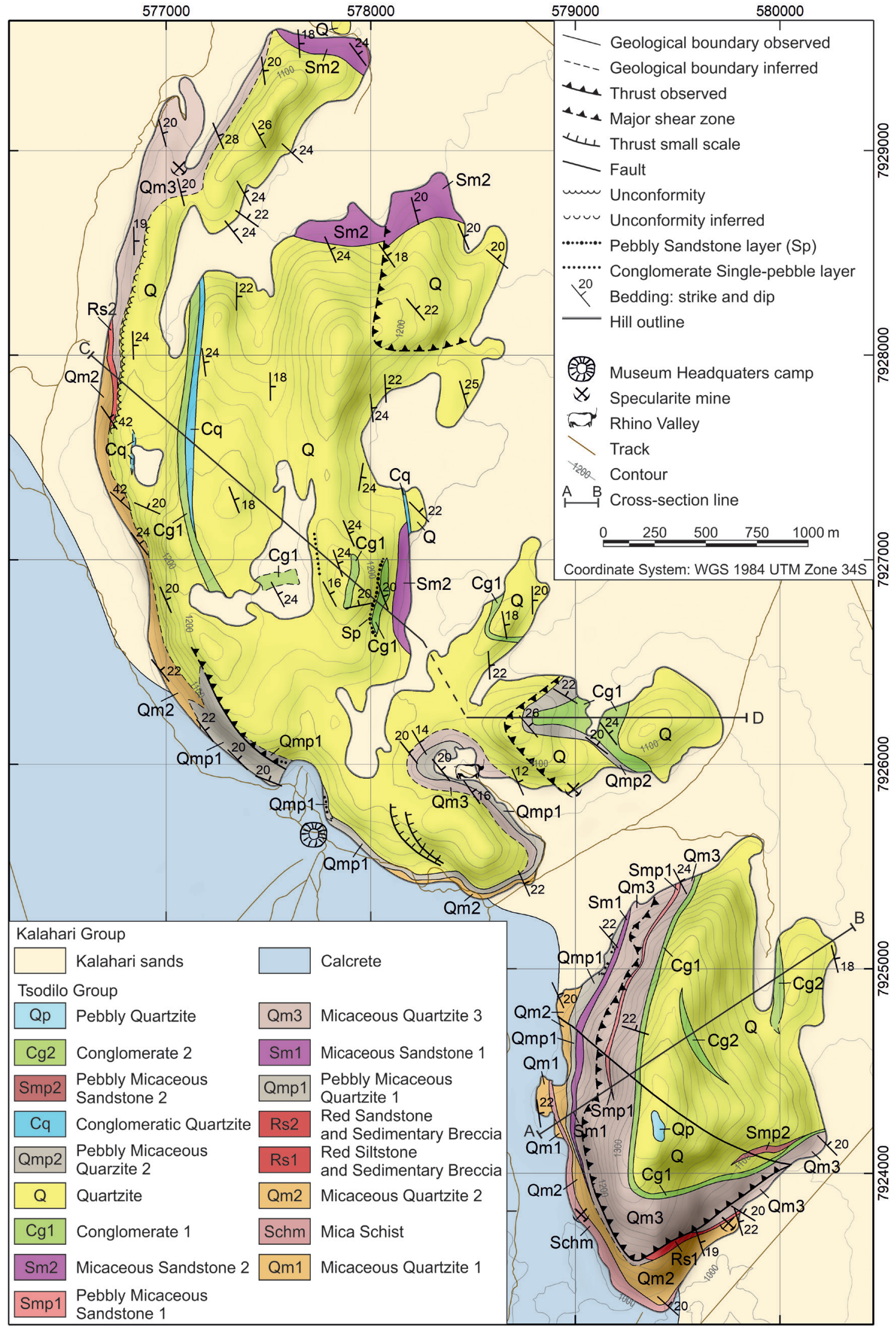

Fig. 3. Geological map of the Tsodilo Hills. Successions of the lithostratigraphic units are shown in Figure 4 

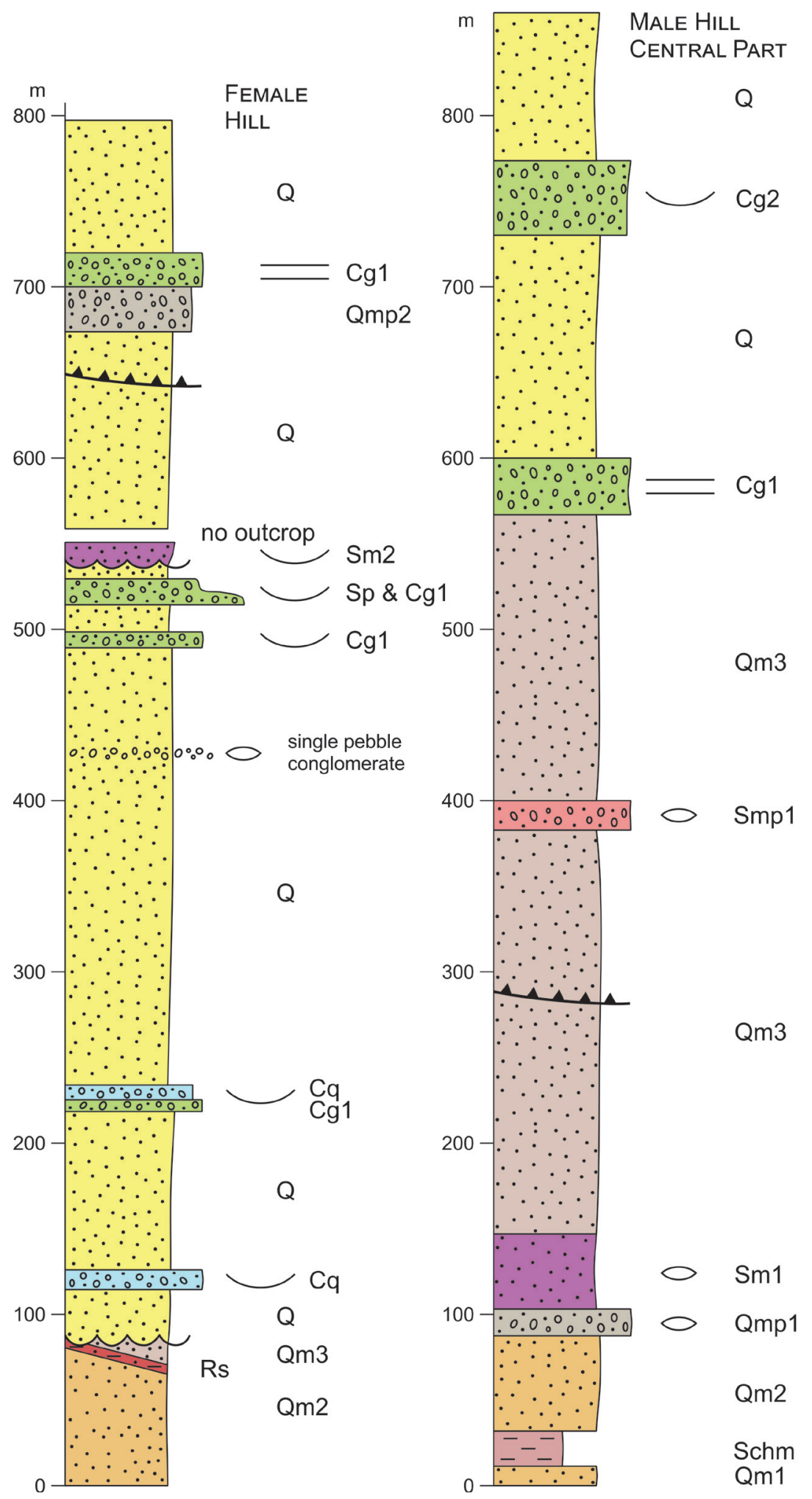

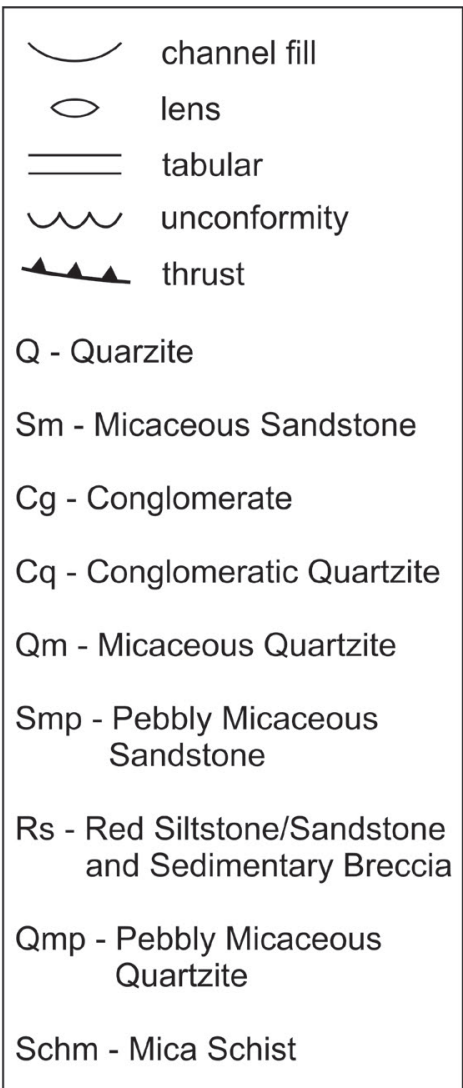

MALE HILL

SOUTH EAST SLOPE

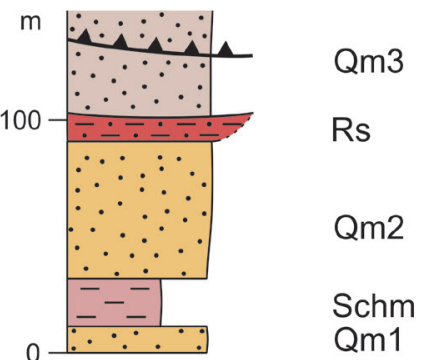

Fig. 4. Lithostratigraphic columns of the Tsodilo Hills Group successions exposed in the Male and Female Hill. The succession of the lithological units reflects their occurrences encountered along cross-section lines shown in Figure 3, i.e. A-B for the Male Hill and a composite section C-D through the Female Hill 
A few minor, but mappable, intercalations that occur beyond the reference lines as local and discontinuous interbeds within the major units, are shown in the logs (Fig. 4) at estimated positions. In those cases where mappable discontinuous bodies occur within major lithostratigraphic complexes, their systematic description is preceded by a paragraph guiding the reader through their inventory and outlining lateral relations. Since strong deformation and foliation of the Tsodilo Hills rocks is limited to narrow zones of thrusting and/or shear, most of the outcrops display well-preserved sedimentary structures.

\section{Male Hill}

Thirteen lithological units constitute the succession mapped in the Male Hill slopes. These are: the lower quartzite (shown on lithological log and map as Qm1), mica schist (Schm), two complexes of micaceous quartzite (Qm2 and Qm3), quartzite containing subordinate conglomerate layers (Qmp1), micaceous sandstone (Sm1), red siltstone associated with sedimentary breccia (Rs), two complexes of pebbly micaceous sandstone (Smp1 and Smp2), conglomerate $1(\mathrm{Cg} 1)$, quartzite $(\mathrm{Q})$, conglomerate $2(\mathrm{Cg} 2)$ and pebbly non-micaceous quartzite (Qp) (Figs. 3 and 4).

\section{Lower quartzite (Qm1)}

The lower quartzite crops out at the base of the Male Hill and is the oldest unit exposed in the Tsodilo Hills succession. The unit is represented by strongly silicified quartzite, fine- to medium-grained, greyish and locally micaceous, which is characterised by swash-type cross-lamination. The lower boundary is covered by the Kalahari sands, and the upper boundary is gradational to the overlying mica schist (Schm). The maximum exposed thickness reaches $15 \mathrm{~m}$.

\section{Mica schist (Schm)}

The mica schist is grey in colour, shows well-developed foliation, contains a high proportion of muscovite flakes and easily crumbles into thin fragments. The unit overlies the lower quartzite (Qm1) conformably and crops out in the lowest part of the SW slope of the Male Hill continuing at the base of the slope where the Lower Quartzite (Qm1) disappears under the Kalahari sands.
The Schm layer has lenticular geometry thinning southward and northward. It is absent in the Female Hill outcrop probably due to facies pinch-out in this direction. The upper boundary to the succeeding unit $(\mathrm{Qm} 2)$ is gradational and the thickness reaches $20 \mathrm{~m}$.

The overlying succession exposed in the Male Hill is dominated by fine- to medium-grained quartzite rich in muscovite and forming two major, laterally continuous complexes labelled Qm2 and Qm3 (Fig. 4). These are separated from each other by three minor units (Qmp1, Sm1 and Rs) of limited lateral extent, which are described later in the text. The Qmp1 and Sm1 units together separate Qm2 from Qm3 in the western slope of the Male Hill, whereas the Rs stratum marks a boundary between them in the south-east. In addition, the middle part of the Qm3 contains a lenticular intercalation of a lithofacies labelled Smp1. All these units are described systematically below.

\section{Micaceous quartzite (Qm2)}

The micaceous quartzite $(\mathrm{Qm} 2)$ is medium- to fine-grained and rich in muscovite. In the lower part of the unit low-angle tabular planar cross-bedded sets are interbedded with intervals of swash-type cross-bedding. This is followed by tabular cross-bedded quartzite overlain by parallel bedding. Some foresets of large-scale cross-bedding that occur above the parallel-bedded quartzite are normally graded and locally deformed by slump structures.

\section{Pebbly micaceous quartzite 1 (Qmp1)}

The pebbly micaceous quartzite crops out in the western slope of the Male Hill and in the S part of the Female Hill. The unit forms a wedge pinching-out southward along the western slopes of the Male Hill, and terminating in the SW slopes of the Female Hill due to lateral facies transition into quartzite units Qm2 and Q. The Qmp1 exposed in the Male Hill is medium- to coarsegrained micaceous quartzite, grey in colour, that varies in a patchy manner, both laterally and vertically, from quartzite containing several discontinuous single-pebble layers to pebbly quartzite with scattered pebbles. The pebbles are composed mainly of vein quartz and range from $0.5 \mathrm{~cm}$ to 
$3 \mathrm{~cm}$ across; in general, the pebble size and proportion increase northwards. The amount of muscovite decreases in the same direction between the Male Hill and the southern part of the Female Hill. These lateral trends suggest that the presence of at least a part of the muscovite corresponds to primary clay content and the energy of the environment was increasing northwards during deposition of the Qmp1. Tabular cross-bedded sets with both tangential and planar cross-bedding predominate and are interbedded with subordinate low-angle, swash-type cross-bedded sets and rare parallel-laminated intervals.

\section{Micaceous sandstone 1 (Sm1)}

The micaceous sandstone $\mathrm{Sm} 1$ is coarse- to very coarse-grained, is greyish in colour and has a massive structure. The rock weathers relatively easily, which reveals a much lower degree of recrystallization and proportion of silicacement than the quartzite facies present in the other units. This division occurs only in the western slopes of the Male Hill above the Qmp1 (quartzite with subordinate conglomerate layers). Towards the south, it oversteps the Qmp1 and wedges out between Qm2 and Qm3.

\section{Red siltstone and sedimentary breccia (Rs1)}

The red siltstone unit crops out in the SE slope of the Male Hill as an association of siltstone and sedimentary breccia, the latter forming an intercalation that extends over a distance of only $3 \mathrm{~m}$ along strike. Sedimentary structures in the siltstone vary from parallel lamination to lenticular bedding with small current ripple marks composed of very fine sandstone. A layer of dark red silty mudstone about $20 \mathrm{~cm}$ in thickness contains phosphorite nodules. The sedimentary breccia consists of randomly oriented angular to subrounded intraclasts of red siltstone embedded in a reddish-brown, in places yellowish, silty matrix. This fragmental rock is generally massive, but locally shows significant porosity due to leaching of clasts not resistant to weathering.

The Rs1 unit attains a thickness of ca. 10 metres and its stratigraphic boundaries with the underlying Qm2 and overlying Qm3 quartzite are sharp. The western termination of the red siltstone outcrop is determined by the overlying thrust surface. In the east this cuts through the overlying
Qm3 unit, but further to the west gradually approaches the top of the Rs1 and meets it in the westernmost part of the outcrop. There, the red bed is incorporated into the major thrust zone, deformed into small recumbent folds and fragmented tectonic breccia, the latter disappearing further to the north. The kinematic indicators fold vergence, striations and slickensides - indicate thrusting to the SW.

\section{Micaceous quartzite (Qm3)}

The quartzite Qm3 is medium- and fine-grained, and is generally rich in muscovite. The lower part is characterized by medium-grained, stacked cosets of trough cross-bedding. This is succeeded by a succession composed of current ripple marks that show bidirectional/bipolar palaeocurrent directions (directed to SE and NW). Locally, the trough cross-bedded complex is overlain by a layer of imbricated pebbles. The upper part of the micaceous quartzite unit is dominated by low-angle tabular planar cross-bedded quartzite interbedded with swash-type cross-bedded quartzite. The major thrust observed in the southern slopes of the Male Hill intersects the Qm3 unit at a generally low angle relative to bedding, displacing strata towards the SW and evolving laterally towards the north into a thin shear zone present in the south-eastern part of the Female Hill.

\section{Pebbly micaceous sandstone 1 (Smp1)}

Micaceous sandstone of the Smp1 unit is mediumto coarse-grained, greyish in colour and contains a subordinate proportion of vein quartz pebbles. The pebbles range in size from 0.5 to $4 \mathrm{~cm}$ and are well-rounded, with sphericity ranging from moderate to low. The lower and upper boundaries of the unit are gradational; laterally it forms a lens within the Qm3 complex wedging out towards the south. It does not continue into the Female Hill slopes to the north.

\section{Conglomerate 1 (Cg1)}

Conglomerate Cg1 forms a tabular body ca. $11 \mathrm{~m}$ thick, extending throughout the Male Hill above the micaceous quartzite Qm3. It reappears in the SE part of the Female Hill, where it is underlain by the pebbly micaceous quartzite (Qmp 2) described further in the text. 
In all examined outcrops, the Cg1 unit is typified by conglomerate beds associated with subordinate layers of quartzite and sandstone. The conglomerate beds range in thickness from 10 to over $200 \mathrm{~cm}$, and contain well-rounded pebbles of vein quartz, jasper and mudstone, most commonly ranging from 0.5 to $8 \mathrm{~cm}$ in diameter. Proportions of finer detritus associated with the pebbles are variable so that the rock ranges from clast-supported to matrix-supported. Matrix-supported conglomerate layers are few and contain an argillaceous matrix with an admixture of heavy minerals and quartz sand grains. The conglomerates are interbedded with subordinate quartzite and sandstone layers. Structurally, the Cg1 unit is characterised by tabular cross-stratified sets mainly ranging in thickness from 20 to $80 \mathrm{~cm}$, while subordinate massive beds are $20-50 \mathrm{~cm}$ thick.

\section{Quartzite (Q)}

This unit is composed of medium- to coarsegrained, generally non-micaceous quartzite rich in strongly recrystallized silica cement. The colour of the rock is mainly greyish, but in places pinkish. In the Male Hill and in the SE part of the Female Hill, it overlies Cg1 with a sharp boundary. In the SW part of the Female Hill it rests upon Qmp1 and Qm3 with gradational contacts. Sedimentary structures are very well-preserved and comprise a variety of cross-bedding: swash, trough, tabular ranging from small to large scale, and hummocky as well as current ripples. In the Male Hill, this unit reaches a maximum thickness of ca. $290 \mathrm{~m}$.

\section{Conglomerate 2 (Cg2)}

Conglomerate $\mathrm{Cg} 2$ forms a lenticular body exposed within the $\mathrm{Q}$ quartzite unit at the eastern slope of the Male Hill, reaching maximum thickness of ca. $12 \mathrm{~m}$ and bounded by sharply-defined contacts. Due to the slope undulations it crops out in both the upper and lower reaches of the slope. The geometry of these outcrops suggests that the $\mathrm{Cg} 2$ lens is at maximum $500 \mathrm{~m}$ wide and minimum $700 \mathrm{~m}$ long. Textural features and mineral composition are very similar to those of the tabular conglomerate unit $\mathrm{Cgl}$, but the sedimentary features are slightly different. The thickness of pebbly conglomerate beds ranges from 20 to $80 \mathrm{~cm}$. They are usually clast-supported, with tabular cross-bedded sets in the lower half of the complex but massive in the upper part. These are interbedded with quartzite and pebbly quartzite beds, $25-100 \mathrm{~cm}$ thick, with tabular cross-bedding in the lowest and uppermost part of the $\mathrm{Cg} 2$, but massive in the middle section. However, in contrast to the Cg1 unit, sandstone interbeds are absent in the Cg2.

\section{Pebbly micaceous sandstone 2 (Smp2)}

This lithofacies forms a small lens with gradational boundaries within the $\mathrm{Q}$ unit exposed in the SE slopes of the Male Hill, immediately above the tabular conglomerate Cgl. The rock is mediumto coarse-grained, greyish in colour and contains a subordinate proportion of vein quartz pebbles, well-rounded, ranging from 0.5 to $4 \mathrm{~cm}$ across with moderate to low sphericity. In general, this occurrence represents the same lithofacies as the pebbly micaceous sandstone 1 (Smpl) that forms a prominent wedge in the underlying quartzite unit Qm3.

\section{Pebbly non-micaceous quartzite $(Q p)$}

The pebbly non-micaceous quartzite $\mathrm{Qp}$ is the stratigraphically youngest unit. It is $10 \mathrm{~m}$ in thickness and is exposed at the peak of the Male Hill. The rock comprises coarse- to very coarse-grained meta-arenite, which is greyish in colour and containing vein quartz pebbles in proportions lower than those present in Qmp 1 and Qmp 2. The rock seems to be massive, but it is possible that weathering has obliterated its sedimentary structures.

\section{Female Hill}

\section{Micaceous quartzite (Qm2)}

The micaceous quartzite Qm2 is the stratigraphically oldest unit exposed in the Female Hill succession, at the foot of the western slope. It is light grey in colour, fine- to coarse-grained, enriched in heavy minerals and containing muscovite, the proportion of which decreases towards the north. A subordinate admixture of pebbles appears in the south and increases in this direction leading to the lateral transition into the pebbly micaceous quartzite (Qmp1) continuing up to here from the Male Hill. Weak foliation observed in the south decreases northwards as well. Sedimentary 
structures are well preserved and these are: largescale tabular cross-bedding, trough cross-bedding, swash cross-stratification, large-scale tabular planar cross-bedding and mud drapes. Trough cross-bedded sets are overlain by large-scale tabular planar cross-bedding with reactivation surfaces. Several beds with tabular tangential cross-bedding that follow are overlain with erosional contact by swash cross-stratification succeeded by subhorizontal to parallel lamination. Megaripples up to $30 \mathrm{~cm}$ high and small ripple marks are scattered within this complex. Cross-bedding often shows alternating palaeocurrent directions towards the NW and the SE.

\section{Pebbly micaceous quartzite 1 (Qmp1)}

The pebbly micaceous quartzite is a lateral facies equivalent to the quartzite with subordinate conglomerate layers identified in the Male Hill and the southernmost part of the Female Hill. The rock is light-grey, fine- to coarse-grained and rich in muscovite. It contains rounded to well-rounded pebbles of very low sphericity of red jasper, mudstone and vein quartz mostly ca. $5 \mathrm{~cm}$ in diameter. A single-pebble layer occurs in the upper part of the unit. There are well-preserved sedimentary structures, most commonly: tabular planar and tangential cross-bedding, current ripples, mud drapes, tidal bundles and swash cross-stratification. The cross-bedded sets reach a thickness of $40 \mathrm{~cm}$ and are bounded by $1-2 \mathrm{~cm}$ thick mudstone beds. Cross-bedding indicates NW- and SE-directed alternating palaeocurrent directions.

\section{Red sandstone and sedimentary breccia (Rs)}

The red sandstone unit crops out in the western slope of the Female Hill as ca. $9.5 \mathrm{~m}$ thick association of three predominant lithologies, i.e. ferruginous sandstone, two lenses of sedimentary breccia and a wedge of quartzite. The lower boundary is depositional and sharply defined on the underlying quartzite Qm2. However, the upper boundary is defined by erosional base of the overlying quartzite unit $\mathrm{Q}$ and is marked by an angular unconformity of $5-10^{\circ}$.

The quartzite wedge occurs in the middle of the red sandstone unit. It is max. $6 \mathrm{~m}$ thick in the southern end of the outcrop and pinches out northwards among the red facies strata. It is composed of tabular cross-bedded sets up to $35 \mathrm{~cm}$ thick and megaripples similar in height. The wedge is underlain by a reddish-brown sandstone interval, which is coarse- to fine-grained, tabular cross-bedded at medium scale, and which contains fine subangular to rounded intraclasts of red massive siltstone. Contained within it are two lenses of sedimentary breccia, each 1-1.5 m thick and ca. $60 \mathrm{~m}$ long. The breccia clasts are brown and reddish-brown in colour and represent three lithological types: well-rounded fragments of ferruginous silty mudstone, subangular fragments of tabular mudstone, and whitish argillaceous flakes 1-2 $\mathrm{mm}$ thick and up to $2 \mathrm{~cm}$ across that are rich in phosphorous minerals (Wendorff 2005). The clasts are supported by the matrix, which changes between the breccia clusters from yellow siltstone to light-grey sandstone. Above the quartzite wedge, there is ferruginous medium- and finegrained sandstone interbedded with mudstone, containing tabular cross-bedded sets up to $30 \mathrm{~cm}$ thick, and truncated at top by the angular unconformity marked by erosional base of the overlying, large-scale cross bedded quartzite unit $(\mathrm{Q})$.

\section{Micaceous quartzite (Qm3)}

The micaceous quartzite overlying the red sandstone interval (Rs) with a sharply defined boundary is in turn overlain unconformably by the non-micaceous quartzite unit $\mathrm{Q}$ in the southern part of outcrop. Towards the north, this boundary evolves into conformable stratigraphic contact; the amount of muscovite decreases in the same direction. In general, the lithofacies association and sedimentary features of Qm3 are very similar to Qm2. The sedimentary structures comprise largescale tabular cross-bedding, swash cross-stratification, hummocky cross-stratification, mud drapes and conspicuous sets of large-scale trough cross-beds overlain by tabular planar cross-bedding with reactivation surfaces.

\section{Non-micaceous quartzite $(Q)$}

The non-micaceous quartzite is whitish to light pinkish in colour, coarse- to fine-grained, often enriched in heavy minerals and locally associated with interbeds of muscovite-bearing quartzite. Quartzite (meta-arenite) beds prevail in the unit, 
however, some beds, or bed-sets, are so weakly silicified that they must be classified as sandstone with silica cement. The unit overlies the micaceous quartzite in the south-western slope of the Female Hill conformably. However, in the central sector of this slope, the lower boundary becomes an erosional angular unconformity on the red sandstone Rs2 and micaceous quartzite Qm3. The basal part of the quartzite $\mathrm{Q}$ immediately overlying the unconformity contains numerous intraclasts, up to $5 \mathrm{~cm}$ in size, of grey mudstone that occurs as interbeds within the underlying continuous succession of Qm2. Farther to the north this local unconformity evolves into a conformable boundary on the micaceous quartzite $(\mathrm{Qm} 3)$.

The non-micaceous quartzite displays a wide range of well-preserved sedimentary structures, most common of which are: medium-scale current ripples, climbing ripples, trough cross-bedding, tabular planar cross-bedding, swash cross-stratification, herringbone cross-bedding, mud drapes, tidal bundles (double mudstone drapes), reactivation surfaces, composite subaqueous dunes and sand waves, and rare symmetrical wave ripples and hummocky cross-stratification (Wendorff 2005). Sand waves, up to $2 \mathrm{~m}$ thick, with composite internal structure and capped by megaripples occur in the northern outcrops of the Q unit. Giant-scale cross-bedding composed of stacked sets up to $6 \mathrm{~m}$ thick, interpreted as open shelf sand waves up to 10 $\mathrm{m}$ thick, overlie the unconformity at the base of the non-micaceous quartzite unit (Q).

The lithofacies Q hosts several small-scale and thin conglomerate layers. These are often discontinuous at the outcrop scale and not mappable. The pebbles reach $6 \mathrm{~cm}$ across, are subangular to subrounded, mainly composed of vein quartz, sometimes red jasper and rarely represent mudstone intraclasts. They are usually supported by arenite composed of quartz and enriched in heavy minerals. Sedimentary structures range from massive to cross-bedded with pebbles dipping to the $\mathrm{N}$, to normally-graded from pebbly-quartzite to medium- or fine-grained quartzite.

\section{Micaceous sandstone 2(Sm2)}

The micaceous sandstone unit is composed of lightgrey, fine- to medium-grained arenite overlying the non-micaceous quartzite $\mathrm{Q}$ at three localities.
The basal contact is gradational, suggesting lateral facies change. The preserved sedimentary structures are medium-scale tabular planar cross-bedding sets about $50 \mathrm{~cm}$ thick, medium-size current ripples and tabular planar cross-beds. Locally, the sandstone contains admixture of granules (0.5$1 \mathrm{~cm}$ across) of vein quartz, jasper and mudstone.

\section{Conglomerate (Cg1) and conglomeratic quartzite $(\mathrm{Cq})$}

In the western part of the Female Hill, a lenticular association ca. $25 \mathrm{~m}$ thick and extending over 1650 $\mathrm{m}$ along strike is formed by very thick beds of conglomerate (Cg1) overlain by pebbly quartzite (Cq). The sole of the conglomerate layer is sharp/erosional and the boundary between the two lithofacies transitional, expressed by a gradual decrease of proportion of pebbles to the quartzite matrix. The lenticular form and erosional character of the lower boundary suggest that this small lithosome fills a shallow but broad erosional feature. Sedimentary structures preserved in the conglomeratic quartzite unit range in scale from large and medium tabular cross-bedding, through trough cross to small ripple marks.

\section{Pebbly micaceous quartzite 2 (Qmp2)}

The pebbly micaceous quartzite unit occurs only in the SE part of the Female Hill where it overlies the non-micaceous quartzite $(\mathrm{Q})$ and is followed by tabular conglomerate $\mathrm{Cg} 1$, which extends there from the Male Hills (see description above). The quartzite constitutes a greyish medium- to coarse-grained matrix containing randomly scattered pebbles. The pebbles are well-rounded, poorly sorted, range from 1 to $4 \mathrm{~cm}$ in diameter and are composed of whitish vein quartz with subordinate brown mudstone intraclasts. It occurs in stratigraphic continuity with the succeeding conglomerate Cg1; therefore, these two lithological divisions form a coarsening-upwards succession.

\section{Conglomerate (Cg1)}

Several mappable occurrences of conglomeratic lithofacies occur interbedded with quartzite complex Q in the Female Hill. In general, they consist of matrix- to clast-supported conglomerate beds 
with a light-greyish and locally pinkish matrix. The pebbles are $2-6 \mathrm{~cm}$ in diameter, are usually subrounded to well-rounded, of low sphericity and composed of jasper, pink vein quartz and pink/reddish mudstone. The lower boundaries of pebbly facies are usually erosional, and lower boundaries of the individual conglomerate beds often appear scoured. The upper boundaries can be transitional from conglomerate to the overlying conglomeratic/pebbly quartzite. In places, transitions from quartzite to the overlying conglomerate are gradational and expressed by a gradual increase in the proportion of pebbles. Structurally, the conglomerate layers often show tabular planar cross-bedding, but can also be massive or normally or inversely graded.

\section{Pebbly sandstone (Sp) and conglomerate (Cg1)}

Pebbly sandstone occurs in the eastern part of the Female Hill as a basal part of an association with the overlying conglomerate (Cg1). The pebbly sandstone is light grey in colour, poorly sorted with sand-grade grains ranging from fine to coarse. It contains scattered pebbles up to $6 \mathrm{~cm}$ across. It forms a layer about $50 \mathrm{~cm}$ thick grading upwards into matrix-supported conglomerate, with the whole association reaching $18 \mathrm{~m}$ in thickness. The sedimentary structures preserved in this association are tabular planar cross-bedded sets about $40 \mathrm{~cm}$ thick, with cross-beds overlain by $1 \mathrm{~cm}$ thick mud drapes, and superimposed medium-scale current ripples.

\section{Conglomerate single-pebble layer (Csp)}

Single pebble conglomerate layers occur at various localities, scattered through the area. They are usually hosted in a fine- to coarse-grained sandy matrix. The pebbles are usually ca. $5 \mathrm{~cm}$ in diameter, subrounded to well-rounded with low degree of sphericity. They are most often composed of vein quartz and sometimes mudstone. Locally, pebble orientation and a constant dip direction is related to cross-bedding. The appearance of a single-pebble layer often implies proximity of a conglomeratic unit either below or above. Sometimes, a one-pebble conglomerate layer continues over a considerable distance, and the most extensive of such beds is shown on the map in the central sector of the Female Hill.

\section{DISCUSSION AND CONCLUSIONS}

\section{Lithological features}

The metasedimentary succession exposed in the Tsodilo Hills is dominated by a quartzite (metasandstone) lithofacies, which contains numerous interbeds of pebbly quartzite, matrix-supported and clast-supported meta-conglomerate, sandstone and pebbly sandstone. Such interbeds range in scale from thin intercalations of local extent and even non-mappable single-pebble conglomerates, to several metres and tens of metres thick units.

Lithologically, the lower part of the Male Hill suite correlates well with the lower part of the succession exposed along the SE slopes of the Female Hill (Fig. 3). In general, the succession exposed in the Male Hill is dominated by three micaceous quartzite complexes (Qm1, Qm2 and Qm3) interlayered with subordinate units of conglomerates and fine-grained meta-sedimentary rocks, most of which form laterally discontinuous complexes. This succession is overlain by a tabular, laterally continuous, conglomerate unit (Cg1) followed by the non-micaceous quartzite complex $(\mathrm{Q})$.

A regressive-transgressive succession is suggested to occur in the western slope of the Female Hill at the transition from Qm2 through Rs2 to Q where a quartzite of beach facies overlies the succession of quartzite, red siltstone and mudstone of tidal flat with infills of tidal channels incised at the top that are overlain by transgression-related quartzites with giant-scale cross bedding interpreted as open shelf sand waves or subaqueous sand bars (see Wendorff 2005 - Fig. 7)

The lower part of the succession from Qm1 to Qm3 correlates well between the Male and Female hills and reveals several genetic features. Among them are several lateral facies changes, most often directional from south to north, i.e. between the Male Hill and Female Hill:

- a significant decrease of muscovite at all scales from the south to the north of the area, i.e.: (i) within individual, wedge-shaped units (e.g. $\mathrm{Sm}$ ) in the Male Hill, and (ii) within Sm3 in the Female Hill, to (iii) the general succession of quartzite complexes generally rich in muscovite in the Male Hill and of markedly decreasing, albeit not entirely devoid of muscovite, in the whole Female Hill succession of the Q unit; 
- the lateral facies transition in the southern part of the Female Hill from pebbly quartzite Qmp exposed in the Male Hill and to almost devoid of pebbles Qm2 and Q; this case serves as excellent, small-scale field example of the Walther's Law of Facies Sequences.

Tidal flat facies associations the Rs1 and Rs2 units were tentatively interpreted in the past by Wendorff (2005) as a record of two separate regressive events. However, it appears that their position in the succession together with the lithological characteristics suggest one and the same regression, the record of which is preserved as two separate occurrences: one in the southern part of the Male Hill (Rs1) and the other in the western slopes of the Female Hill (Rs2); therefore, they can be correlated. The palaeogeographical separation of their outcrops could have occurred due to differential subsidence or synsedimentary tectonic movements that affected the basin floor, resulted in tilting of the sector that is now exposed in the western slope Female Hill and erosion of a part of the tidal-flat sediments prior to the onset of deposition of the Q unit.

Tiny tabular argillaceous intraclasts enriched in phosphorous minerals in the red-bed facies in the Female Hill (unit Rs) are interpreted as desiccation flakes eroded from a dried-up mudflat surface (eg. Pflüger \& Gresse 1996).

The angular unconformity between tidal-flat Rs2 and the overlying quartzite Q in the Female Hill west slopes implies synsedimentary tilting of the depositional surface, reflecting either differential subsidence or tectonic movements within the basin.

Pebbles in the conglomerate and conglomeratic quartzite beds are usually well to very-well rounded but of low sphericity, elongated but with short $\mathrm{C}$ axes. Such shape parameters reflect a high degree of flatness suggestive of abrasion in the beach environment, from which they were redeposited offshore (Durian et al. 2006, Domokos et al. 2010).

Lenticular conglomerate and conglomeratic quartzite, or sandstone, bodies with sharp, erosional lower boundaries, sometimes beginning with pebble-rich layers reminiscent of channel lag, are interpreted here as infills of local, broad channel-like incisions in the open shelf sandy sediments. Erosion and subsequent deposition of such coarse clastic facies might have been caused by storm events generating rip current chutes (e.g.
Antia 1994, Aagaard et al. 1997). Coarse-grained storm layers observed even $40 \mathrm{~km}$ away from a pebbly shoreline were reported by, for example, Reineck \& Singh (1975).

In general, the limited-scale but mappable units form wedges and lenses. The largest body of this type extends in the map view over a maximum distance of ca. $1700 \mathrm{~m}$ (Cg1-Cq in the Female Hill), while the least extensive is the lens of Smp2 outcropping in the eastern part of the Male Hill. Only two lithological units interbedded within the predominant quartzite (metasandstone) succession were deposited as layers extending continuously throughout the whole area: (i) the red sandstone-siltstone-mudstone-conglomerate association (Rs), the originally genetic continuity of which is explained above, and (ii) the tabular conglomerate unit Cg1 present in the upper part of the succession. The thickness of the latter changes from ca. $30 \mathrm{~m}$ in the Male Hill to about $10-15 \mathrm{~m}$ in the SE part of the Female Hill and its broad extent is considered to reflect the second regression recorded by an increased input of coarse-clastic detritus into the basin.

The lateral trends of the muscovite content between the Male Hill and Female Hill successions, which in places is also associated with changes of proportions of the pebbly material and a sudden occurrence of Sm2 unit within the Q-type strata suggest that the presence of at least a part of muscovite is related to primary clay content in the sandy and pebbly sediment. Consequently, it is inferred that the energy of the environment was periodically varying and the lateral gradient of its changes is recorded along the N-S direction.

\section{Lithostratigraphic relations of the Tsodilo Hills Group in the Tsodilo Hills}

In spite of being dominated by quartzites and quartz arenites, the suite exposed in the Tsodilo Hills displays lithostratigraphic features that vary in the vertical succession as well as laterally. In the lower part of the depositional sequence a succession of the following lithological complexes Qm1, Schm, Qm2, Qmp1 and Rs1 is exposed in the Male Hill slopes (Figs. 3 and 4). The characteristic marker unit Rs consists of two occurrences of the red bed associations Rs1 and Rs2 correlated between the Male Hill and Female Hill. The upper boundary of the red-bed association varies laterally within the Male Hill from stratigraphic (depositional) in 
the SE slopes where the Rs1 is conformably overlain by Qm3, to tectonic contact in the $\mathrm{W}$ slopes where it is truncated by the major thrust (Fig. 3). In the $\mathrm{W}$ slope of the Female Hill the upper boundary of Rs 2 unit changes laterally from erosional contact associated with an angular unconformity between Rs2 and the overlying unit Q to stratigraphic (depositional) with the succeeding Qm3 (Figs. 3 and 4).

The best exposed and accessible strata overlying the red-bed (Rs) association occur in the Female Hill slopes, where they form the following lithological complexes: the non-micaceous quartzite $\mathrm{Q}$, which contains laterally discontinuous interbeds of conglomerate, pebbly sandstone and single-pebble conglomerate $(\mathrm{Cq}, \mathrm{Cg} 1, \mathrm{Sp}$, Qmp2). This succession evolves laterally towards the Male Hill into the micaceous quartzite Qm that is succeeded by non-micaceous quartzite containing one lens of $\mathrm{Cg} 2$ conglomerate. The tabular body of $\mathrm{Cg} 1$ conglomerate extends between the Male Hill and Female Hill (Figs. 3 and 4) and separates the underlying micaceous quartzite Om3 from the overlying it non-micaceous quartzite unit (Q) in the Male Hill. A continuation of this pebbly marker within the $\mathrm{Q}$ unit in the SE part of the Female Hill outcrop emphasises the lateral transition from the generally muscovite-rich part of the Male Hill succession to its muscovite-poor equivalent in the Female Hill slopes.

This work was financially supported by the AGH University of Science and Technology Statutory Research Grant No. 15.11.140.638 to MW and AS, and by the University of Botswana Research Grant No. R270 to MW. Constructive suggestions of the Reviewers - D.T. Aldiss, M. Cieszkowski and R.M. Key - helped to improve an earlier version of this paper and are here gratefully acknowledged.

\section{REFERENCES}

Aagaard T., Greenwood B. \& Nielsen J., 1997. Mean currents and sediment transport in a rip channel. Marine Geology, 140 (1-2), 25-45.
Antia E., 1994. Long-term and post-storm dynamic patterns of the subtidal rhythmic morphology along the East Frisian island coast, Germany. Geologie en Mijnbouw, 73 (1), $1-12$

Carney J.N., Aldiss D.T. \& Lock N.P., 1994. The Geology of Botswana. Bulletin, 37, Geological Survey of Botswana, Lobatse.

Domokos G., Sipos A., Szabó T. \& Várkonyi P., 2010. Pebbles, shapes, and equilibria. Mathematical Geosciences, 42 (1), 29-47.

Durian D.J., Bideaud H., Duringer P., Schröder A., Thalmann F. \& Marques C., 2006. What is in a pebble shape? Physical Review Letters, 97 (2), 028001.

Ingram R.L., 1954. Terminology for the thickness of stratification and parting units. Geological Society of America Bulletin, 65, 937-938.

Key R.M. \& Ayers N., 2000. The 1998 edition of the National Geological Map of Botswana. Journal of African Earth Sciences, 30, 427-451.

Mapeo R.B.M., Wendorff M., Ramokate L.V., Armstrong R.A., Mphinyane T. \& Koobokile M., 2019. Zircon geochronology of basement granitoid gneisses and sedimentary rocks of the Tsodilo Hills Group in the Pan-African Damara Belt, western Botswana: age constraints, provenance, and tectonic significance. Journal of African Earth Sciences, 159, 103576.

Meixner H.M. \& Peart R.J., 1984. The Kalahari Drilling Project. Bulletin, 27. Geological Survey of Botswana, Lobatse.

Pflüger F. \& Gresse P.G., 1996. Microbial sand chips - a non-actualistic sedimentary structure. Sedimentary Geology, 102 (3-4), 263-274.

Reineck H.E. \& Singh I.B., 1973. Depositional Sedimentary Environments: with Reference to Terrigenous Clastics. Springer-Verlag Berlin Heidelberg.

Singletary S.J., Hanson R.E., Martin M.W., Crowley J.L., Bowring S.A., Key R.M., Ramokate L.V., Direng B.B. \& Krol M.A., 2003. Geochronology of basement rocks in the Kalahari Desert, Botswana, and implications for regional Proterozoic tectonics. Precambrian Research, 121, 47-71.

Vermaak C.F., 1962. Batawana Reserve - Bechuanaland Protectorate Geological Report. Johannesburg Consolidated Investment Company Ltd., Johannesburg.

Wendorff M., 2005. Outline of lithostratigraphy, sedimentation and tectonics of the Tsodilo Hills Group, a Neoproterozoic-Lower Palaeozoic siliciclastic succession in NW Botswana. Annales Societatis Geologorum Poloniae, 75 (1), 17-25.

Wentworth C.K., 1922. A scale of grade and class terms for clastic sediments. The Journal of Geology, 30 (5), 377392.

Wright E.P., 1956. The Tsodilo Hills (Ngamiland). EPW/15/56, Unpublished Report EPW/15/56. Geological Survey of Botswana, Lobatse. 